\title{
INSTITUTIONAL INEQUALITY AND THE DYNAMICS OF COURAGE
}

\section{Colleen Sheppard*}

One of the greatest challenges of anti-discrimination law is institutionalized inequality. Recognized in law as systemic discrimination, it is embedded in processes, practices, norms, and relationships that reproduce and accentuate inequality. Legal recognition of the phenomenon, though of critical importance, has not led to effective remedies. Retroactive individual remedies are often too little, too late, following years of slow-moving and difficult litigation. Systemic, proactive laws have been thwarted by institutional resistance to externally imposed change and/or captured by the power of the institutional status quo. This paper explores the challenges of institutional transformation using the idea of courage - the experience of discouragement, encouragement by institutional change-makers, and the power of solidarity to encourage change from the bottom up.

L'inégalité institutionnalisée est l'un des plus grands défis du droit de la discrimination. Reconnue en droit en tant que discrimination systémique, elle fait partie intégrante des processus, pratiques, normes et rapports qui reproduisent et accentuent l'inégalité. Bien que la reconnaissance juridique du phénomène soit d'une importance critique, elle n'a pas mené à des recours efficaces. Les recours individuels rétroactifs sont souvent inadéquats et trop tardifs et ne sont accordés qu'après des années de litiges lents et ardus. Des lois systémiques et proactives ont été contrecarrées par la résistance institutionnelle au changement imposé de l'extérieur ou défaites par le pouvoir du statu quo institutionnel. Le présent article examine les défis de la transformation institutionnelle en utilisant l'idée du courage - l'expérience du découragement, l'encouragement par les agents institutionnels du changement, ainsi que le pouvoir de la solidarité pour encourager le changement de bas en haut.

\section{INTRODUCTION}

One of the greatest challenges of anti-discrimination law is institutionalized inequality. Recognized in law as systemic discrimination, it is embedded in processes, practices, norms and relationships that reproduce and accentuate inequality. ${ }^{1}$ Legal recognition of the phenomenon, though of critical importance, has not led to effective remedies. Retroactive individual remedies are often too little, too late, awarded after years of slow-moving and difficult litigation. Systemic, proactive laws have been thwarted by institutional resistance to externally imposed change and/or captured by the power of the institutional status quo. ${ }^{2}$ This paper explores the challenges of institutional transformation drawing on the idea of courage: the experience of discouragement, encouragement by institutional change-makers, and the power of solidarity to encourage change from the bottom up.

My decision to explore the multiple dynamics of courage was inspired by Judge Juanita Westmoreland-Traoré - a wise and inspiring scholar, dean, public servant, lawyer and judge - who was

* Faculty of Law, McGill University and Director, Centre for Human Rights and Legal Pluralism. I wish to thank Adelle Blackett and Tamara Thermitus for their helpful comments and suggestions on an earlier draft of this article. Special thanks to McGill law students, Anne-Claire Gayet and Cee Strauss, for their research and editorial assistance.

1 The Supreme Court of Canada recognized the legal concept of systemic discrimination in its pathbreaking decision in $C N$ v Canada (Canadian Human Rights Commission), [1987] 1 SCR 1114 at 1139 [CN v Canada (CHRC)]. See also, discussion in Colleen Sheppard, Inclusive Equality: The Relational Dimensions of Systemic Discrimination in Canada (Montreal: McGill-Queen's University Press, 2010) at 28 and 73 [Sheppard, Inclusive Equality].

2 See Linda Hamilton Kreiger, "Afterword: Socio-Legal Backlash” (2000) 21 BJELL 475. 
appointed as the first black judge in the history of Quebec and the first black dean of a law school in Canada's history, as Dean of the Faculty of Law at the University of Windsor. In reflecting upon her significance to my life and work, the word that kept coming to mind was encouragement. ${ }^{3}$ In all of my encounters with Judge Westmoreland-Traoré, I have felt encouraged - deeply encouraged. She has a way of reinforcing my belief in my abilities and has often made me more willing to try to do something I was uncertain I would be able to do. When I looked up the etymology of the word "encouragement," I found that it is derived from the Old French word "encoragier." It combines both "en" which means "to make" and "corage," which means "courage or courageous." Its etymology is also derived from "cor," meaning with heart, or daring. ${ }^{4}$ I was struck by how precisely the etymology of encouragement captures what Judge Juanita Westmoreland-Traoré means to me; she makes me more courageous and daring, in both my heart and mind.

In this article, therefore, I highlight three ways in which the idea of encouragement is relevant to thinking about law and equality. I suggest that attentiveness to the dynamics of courage (both encouragement and discouragement) provides insights into the institutional realities of equality and inequality. The first dynamic that I discuss is negative; individuals and groups, in contexts of institutionalized inequality, often become deeply dis-couraged and disempowered. This discouragement is one of the harms of systemic discrimination and institutional inequality. The second is more positive and focuses on encouragement by individual change-makers, who can effectively bridge diverse identities across institutional divides of power and privilege. The third dynamic is also positive. It highlights the ways in which individual acts of courage are fostered by solidarity (often amongst those at the bottom of institutional hierarchies), as well as by family and community support networks.

\section{FIRST DYNAMIC OF COURAGE: DISCOURAGEMENT AND ENTRENCHED INSTITUTIONAL INEQUALITIES}

$$
\begin{aligned}
& \text { So ... I was discouraged, broken. } \\
& \text { Shirley Thomas }
\end{aligned}
$$

\section{A. Cycles of Inequality and Discouragement}

Turning to the first dynamic of courage, how does discouragement relate to legal concepts of discrimination and inequality? Over the past 30 years, we have witnessed a significant expansion in our understanding of the meaning of discrimination. Historically, discrimination was understood as direct, differential, and prejudicial treatment linked to overtly discriminatory attitudes, stereotypes, and beliefs about certain groups. While it still often involves such characteristics, discrimination has now expanded to encompass adverse effects discrimination, borne of the disparate effects of seemingly neutral

3 This article is based on a presentation I gave at a Conference to honour the work and contributions of the Honourable Juanita Westmoreland-Traoré: Social Justice, Law and Equality: A Conference in Honour of Judge Juanita Westmoreland-Traoré, Centre for Human Rights and Legal Pluralism, McGill University, 16-17 March 2012 online: McGill University <http://www.mcgill.ca/humanrights/aisenstadt/knowledge/westmoreland-traore>.

4 See e.g. "encouragement", online: CNRTL <http://www.cnrtl.fr/etymologie/encouragement>.

5 Testimony, Commission des droits de la personne et des droits de la jeunesse c Gaz métropolitain inc., 2008 QCTDP 24 at para 555, a systemic sex discrimination case [Gaz métropolitain, TDP]. 
institutional policies or practices. ${ }^{6}$ Moreover, the legal definition of discrimination has been further enlarged to include systemic discrimination, which is dynamic and embedded in institutional structures, practices, norms, attitudes, and decision-making processes.

Systemic discrimination, first recognized by the Supreme Court of Canada in the late 1980s in a case involving gender-based discrimination in employment, has been described as follows:

[S]ystemic discrimination in an employment context is discrimination that results from the simple operation of established procedures of recruitment, hiring and promotion, none of which is necessarily designed to promote discrimination. The discrimination is then reinforced by the very exclusion of the disadvantaged group because the exclusion fosters the belief, both within and outside the group, that the exclusion is the result of "natural" forces, for example, that women "just can't do the job" [...]. To combat systemic discrimination, it is essential to create a climate in which both negative practices and negative attitudes can be challenged and discouraged. ${ }^{7}$

Systemic discrimination, therefore, includes both direct and adverse effects discrimination (although it is often associated more readily with the latter). ${ }^{8}$ Of most significance, however, is the way in which it reproduces itself over time. Discrimination breeds further discrimination, both intentional and unintentional. Susan Sturm describes a similar shift towards what she calls "second generation discrimination," in which "[c]ognitive bias, structures of decision-making, and patterns of interaction

6 These two types of discrimination, direct and adverse effects (or indirect) discrimination, were first recognized in Ontario Human Rights Commission v Simpson-Sears [1985] 2 SCR 536 in the statutory human rights context, and then in Andrews $v$ Law Society of British Columbia [1989] 1 SCR 143 with respect to the constitutional definition of discrimination. In the statutory context, see also: British Columbia (Public Service Employee Relations Commission) $v$ BCGSEU, [1999] 3 SCR 3 [Meiorin]; and Moore v British Columbia (Education), [2012] 3 SCR 360. For more recent decisions acknowledging both direct and adverse effects discrimination in the constitutional context, see: $R v$ Kapp [2008] 2 SCR 483 at para 18; Withler v Canada (Attorney General), [2011] 1 SCR 396 at para 29. For a reaffirmation of the importance of an effects-based approach to constitutional discrimination, see Quebec (Attorney General) v A, 2013 SCC 5, [2013] 1 per Abella J. (writing for a majority of justices on the meaning of s. 15(1) of the Charter) at para 327: "We must be careful not to treat Kapp and Withler as establishing an additional requirement on s. 15 claimants to prove that a distinction will perpetuate prejudicial or stereotypical attitudes towards them. Such an approach improperly focuses attention on whether a discriminatory attitude exists, not a discriminatory impact, contrary to Andrews, Kapp and Withler."

7 CN v Canada (CHRC), supra note 1 at 1139 per Dickson CJ. See also: Meiorin, supra note 6. For a recent discussion, see Moore v British Columbia (Education), 2012 SCC 61 at para 59 (Although Abella J. suggests that individual and systemic discrimination are simply "quantitatively different," there is a risk that dichotomizing them in this way does not recognize the qualitative differences between the two and the dynamic complexity of systemic, institutionalized inequalities.) For an interesting discussion of systemic problems in the administration of laws, resulting in discrimination, and the importance of remedies, see Little Sisters Book and Art Emporium v Canada (Minister of Justice), [2000] 2 SCR 1120.

$8 \quad$ See, e.g. Saskatchewan (Human Rights Commission) v Whatcott, 2013 SCC 11, [2013] 1 SCR 467 at para 126 dichotomizing intentional versus systemic discrimination - to underscore the important link between systemic discrimination and effects-based discrimination, citing Dickson C.J. in Canada (Human Rights Commission) v Taylor, [1990] 3 SCR 892 at 931-32. As noted above, I maintain that systemic discrimination often combines both intentional and unintentional discrimination.

9 Susan Sturm, "Second Generation Employment Discrimination: A Structural Approach" (2001) 101 Colum L Rev 458 [Sturm, "A Structural Approach"]. 
have replaced deliberate racism and sexism as the frontier of much continued inequality." ${ }^{10}$ Sturm continues:

Second generation claims involve social practices and patterns of interaction among groups within the workplace that, over time, exclude non-dominant groups. Exclusion is frequently difficult to trace directly to intentional, discrete actions of particular actors, and may sometimes be visible only in the aggregate. Structures of decision-making, opportunity, and power fail to surface these patterns of exclusion, and themselves produce differential access and opportunity. ${ }^{11}$

To understand these emerging systemic and structural forms of discrimination, therefore, we need to examine institutional processes and decision-making practices, focusing in particular on how institutional power and privilege are disproportionately enjoyed, reproduced, and entrenched. Discouragement emerges as an important component that shapes the dynamic and cyclical institutional contexts of inequality.

\section{B. Inequitable Institutional Resources, Networks and Social Capital}

Beyond the overt discouragement that some individuals face, there are many subtle sources of discouragement that operate over time, sometimes imperceptibly. Two such sources of discouragement are the inequitable distribution of institutional resources and disparities in access to social capital. ${ }^{12}$ Both have a critical impact on institutional success and advancement. Individuals from historically underrepresented groups often lack the informal networks and resources so critical to recognition, opportunities and success. Moreover, the inequitable conferral of privileges, resources and social capital benefits on individuals from more privileged and historically dominant groups reinforce their opportunities for success in institutional settings. In turn, their institutional success justifies the further bestowal of privileges in their favour and a cycle of systemic inequality deepens.

While there are, of course, many individuals from historically disadvantaged or underrepresented groups who successfully gain admission, promotion, and recognition, too many members of these groups continue to be excluded or denied the support or recognition they deserve. ${ }^{13}$ In such contexts, we begin to witness a dynamic of discouragement. Discouragement, as a dimension of systemic discrimination, undermines self-esteem and self-confidence, instilling doubt as to one's abilities and pressures to conform to dominant norms and assimilate into the institutional status quo. ${ }^{14}$ Thus, it is important to be attentive to how institutionalized processes and practices reinforce historical patterns of

$10 \quad$ Ibid at 460 .

11 Ibid.

12 On social capital, see Robert D Putnam, Bowling Alone: The Collapse and Revival of American Community (New York: Simon \& Schuster, 2000). See also Policy Research Initiative, Social Capital: Building on a Network-Based Approach. Draft discussion paper (Ottawa: Policy Research Initiave, October 2003); Sheppard, Inclusive Equality, supra note 1 at 59.

13 See e.g. group-based statistical patterns of exclusion and underrepresentation: Employment Equity Annual Report (2011) (Canada): online HRSDC <http://www.labour.gc.ca/eng/standards_equity/eq/pubs_eq/annual_reports/2011/docs/ee2011.pdf $>$.

14 Patricia Faison Hewlin, "Wearing the cloak: Antecedents and consequences of creating facades of conformity" (2009) 94: 3 Journal of Applied Psychology 727. See also, Devon W Carbado \& G Mitu Gulati, "The Fifth Black Woman” (2001) $11 \mathrm{~J}$ Contemp Leg Issues 701. 
privilege, inclusion and exclusion, turn hope into hopelessness, confidence to loss of confidence, and the belief in future success to resignation and fear of failure.

\section{Unconscious or Implicit Bias and Cultures of Exclusion}

We are guilty of unconscious discrimination against women by never identifying and developing their talents.

$$
\text { Male CN Rail Employee }{ }^{15}
$$

Organizational culture encompasses shared patterns of informal behaviour, such as communication, decision making and social interaction, which are the observable evidence of deeply held and largely unconscious values, assumptions and norms. Prevailing organizational values and norms are socially constructed by dominant groups and typically reflect the standpoint of members who are white, male, heterosexual and able-bodied.

Beyond the dynamics of discouragement for those within institutions, dynamics of discouragement also affect those who are excluded - often dissuading individuals from even applying for positions or seeking inclusion in institutional settings. In an important systemic discrimination case in Quebec, $G a z$ métropolitain inc. $v$ Commission des droits de la personne et des droits de la jeunesse, a ruling of the Quebec Human Rights Tribunal finding systemic gender-based discrimination was upheld on appeal by the Quebec Court of Appeal. ${ }^{16}$ As explained by Judge Rivet of the Quebec Human Rights Tribunal, systemic discrimination in the workplace is "maintained through an institutional culture permeated with biases, prejudices and unconscious stereotypes that favour the people already in the workplace and gear candidate selection toward people similar to those already holding the job, thereby perpetuating the exclusion of people who have not had an opportunity to penetrate the workplace." 17 Following an extensive review of the evidence, Judge Rivet concludes that the external hiring process was "contaminated by subjectivity, arbitrariness and [...] discretion," 18 resulting in gender-based discrimination that had the effect of discouraging women applicants in the application process.

Of particular significance in Judge Rivet's decision is her recognition of the link between systemic discrimination and unconscious or implicit bias. After reviewing leading Canadian cases on employment discrimination, she makes reference to the notion of unconscious bias, defining systemic discrimination as "the cumulative effects of disproportionate exclusion resulting from the combined impact of attitudes

15 Quotation of a male supervisor in a Report done by CNN on sex discrimination in the workplace, entitled, "Canadian National Action Programs - Women" (Boyle/ Kirkman Report), cited by the SCC in CN v Canada (CHRC), supra note 1 at 1121 .

16 Gaz métropolitain TDP, supra note 5; upheld, except for part of the remedial order according punitive damages to some of the victims and requiring a committee to address sexual harassment: see Gaz métropolitain inc. c Commission des droits de la personne et des droits de la jeunesse, 2011 QCCA 1201 (Can LII) [Gaz métropolitain CA]. As noted by Rochon JA at para 77:

Bref, l'analyse fouillée de la juge et sa conclusion selon laquelle le processus de sélection à l'externe mis en place par Gaz Métro dans un dessein de recruter davantage de femmes a été irrémédiablement entaché de discrimination systémique a été largement démontré et ne souffre pas d'erreur qui puisse justifier l'intervention de la Cour.

17 Gaz métropolitain TDP, supra note 5 at para 446.

$18 \quad$ Ibid at para 444. 
marked by often unconscious biases and stereotypes, and policies and practices generally adopted without taking into consideration the characteristics of the members of groups contemplated by the prohibition of discrimination." 19 The subtle and unconscious dimensions of systemic discrimination, moreover, make it difficult to recognize and to prove in court.

Les fondements sociétaux de la discrimination systémique, ses manifestations subtiles et le fait qu'elle découle de motivations habituellement inconscientes ne sont pas sans conséquence sur les difficultés, pour la partie en demande, d'en établir par prépondérance de preuve l'existence à travers ses diverses manifestations. 20

She recognizes, therefore, the difficult burden of proving discrimination when it stems from accepted institutional practices and unconscious biases.

The criminal justice system is another context where the unconscious dimensions of discrimination and racial profiling are critical concerns. ${ }^{21}$ In a pathbreaking decision on racial profiling in Quebec, The Queen v. Campbell, ${ }^{22}$ Judge Westmoreland-Traoré acquitted an accused youth on charges of possession of drugs for the purposes of trafficking. In clarifying the concept of racial profiling, Judge Westmoreland-Traoré explains that as "with other systemic practices, racial profiling can be conscious or unconscious, intentional or unintentional. Racial profiling by police officers may be unconscious." ${ }^{23}$ In this regard, she cites a leading Ontario case on racial profiling where the Court acknowledged that "[t]he attitude underlying racial profiling is one that may be consciously or unconsciously held. That is, the police officer need not be an overt racist. His or her conduct may be based on subconscious racial stereotyping."24 After assessing the conduct of the police, Judge Westmoreland-Traoré concludes that racial profiling had occurred in violation of equality guarantees and entitlements to fair searches and seizures under the Charter. In acquitting the youth, she clarifies that "[w]hile the racial profiling may have been practiced unconsciously, the good faith of the officers does not restore the right of all citizens to non-discriminatory treatment.",25 These Quebec judgments illustrate how courts can effectively rely on unconscious bias theory to underscore recognition that sexism and racism exist, whether intentional

19 Ibid at para 36 (emphasis added).

20 Ibid at para 37. The English translation reads: "The societal underpinnings of systemic discrimination, its subtle manifestations and the fact that it stems from usually unconscious motivations are not without consequence for the difficulties encountered by a plaintiff in establishing systemic discrimination, by preponderant evidence, through its various manifestations."

21 See Quebec Human Rights and Youth Rights Commission, "Racial Profiling and Systemic Discrimination of Racialized Youth, Report of the Consultation on Racial Profiling and its Consequences" (2011) online: CDPDJ

$<$ http://www.cdpdj.qc.ca/publications/profiling_final_en.pdf> . See also David Tanovich, The Colour of Justice: Policing Race in Canada (Toronto: Irwin Law, 2006).

$22 \quad R$ v Campbell, (2005) QCCQ 2337 (Can LII) (Cour du Québec) [Campbell]. See also, Commission des droits de la personne et des droits de la jeunesse c. Montréal (Service de police de la ville de) (SPVM), 2012 QCTDP 5 (CanLII) online : CanLii <http://www.canlii.org/en/qc/qctdp/doc/2012/2012qctdp5/2012qctdp5.pdf> (unofficial English translation) at paragraphs 152-174 (for a review of legal developments on racial profiling).

23 Campbell, ibid at para 34.

$24 \quad R v$ Brown, 64 OR (3d) 161 at 165; 2003 ONCA 52142 (CanLII) at para 8 [ $R v$ Brown], cited in Campbell, ibid at para 34.

25 Campbell, ibid at para 115. See also Beatrice Vizkelety. "Revisiting the Prima Facie Case and Recognizing Stereotypes Based on Unconscious Bias in Racial and Ethnic Discrimination" (2013) 20 Charter and Human Rights Litigation 1755. 
or not, and that unconscious bias is a contextual reality to keep in mind when addressing the facts of a case.

References to the notion of unconscious bias can also be found in numerous judgments outside of Quebec, particularly in cases involving race discrimination. ${ }^{26}$ Judges have recognized that we live in a society in which racism is pervasive, and as a result, our actions and/or behaviour with respect to racialized individuals may well be racist whether or not we intend them to be, because we are all products of our society. ${ }^{27}$ Thus the notion of unconscious bias is brought in "to lessen the expectation that the respondent's behaviour will necessarily be accompanied by some overt sign of racial bias or prejudice."28 As with the systemic discrimination identified by Judge Rivet in Gaz métropolitain, the unconscious bias dimensions of racial profiling make it difficult to prove, and courts have recognized that "proof will most often be indirect" 29 or "done by inference drawn from circumstantial evidence." 30 It is important to note that recognition of unconscious bias in the Canadian context provides new ways of understanding how direct differential treatment can be a component of systemic discrimination. Whereas legal scholarship traditionally associates unintentional discrimination with the adverse effects of facially neutral policies or rules, implicit bias research helps us to understand the possibility of unintentional discrimination, rooted in implicit or unconscious bias, in relation to direct differential treatment of individuals based on their membership in particular social groups. ${ }^{31}$

The reality of unconscious bias may also explain an important asymmetry in experiential knowledge. There is often a marked divergence of perception between individuals who experience subtle or overt exclusion and inequitable access to resources or privileges, and those whose choices and decisions (which may be affected by unconscious bias) risk having discriminatory effects. Thus, individuals from groups that have been historically underrepresented or excluded are acutely aware of inequities and exclusion, and become discouraged about their prospects for success within an organization. In contrast, those in positions of power within societal institutions may completely overlook or fail to comprehend the possibility that individuals (particularly those from groups that are underrepresented within an institution) could experience discouragement. It is significant, therefore, that judges and adjudicators are increasingly recognizing the realities of unconscious bias in the face of allegations of discrimination. Theories of implicit or unconscious bias further underscore the need for proactive employment and educational equity initiatives to counteract the ongoing risks of discriminatory exclusion and denials of opportunities and resources.

26 See e.g. Shaw v Phipps, 2012 ONCA 155 [Shaw]; Nassiah v Peel, 2007 HRTO 14 [Nassiah]; Peel Law Association v Pieters, 2013 ONCA 396 [Pieters]; Radek v Henderson Development (Canada) and Securiguard Services (No. 3 ), 2005 BCHRT 302 [Radek]; Troy v Kemmir Enterprises Inc., 2003 BCSC 1947 [Troy].

27 See e.g. $R v S(R D)$, [1997] 3 SCR 484 at para 46, L'Heureux-Dubé J and McLachlin J (as she then was) (citing with approval Doherty JA's remarks in $R v$ Parks, 15 OR (3d) 324; [1993] OJ No 2157 at 342.)

28 Vizkelety, supra note 26 at 1762 , n 52.

29 Campbell, supra note 23 at para 35.

$30 \quad R v$ Brown, supra note 25 at para 8, cited in Campbell, supra note 23 at para 35.

31 See discussion in Audrey Lee, "Unconscious Bias Theory in Employment Discrimination Litigation" (2005) 40 Harv CR-CLL Rev 481 at 483-86 [Lee]. For compelling examples of differential treatment based on race, where tribunals raise unconscious bias, see jurisprudence supra note 27. 
Judicial recognition of the effects of unconscious bias in Canada resonates with research in the field of social cognition and psychology. ${ }^{32}$ While unconscious bias is often simply noted without specific social science references in Canadian cases, in the United States, jurists are linking their arguments more directly to the research of social cognition theorists. ${ }^{33}$ The growing and rich literature on implicit or unconscious bias in anti-discrimination law in the United States, however, has also prompted considerable debate. Some US scholars maintain that the concept of implicit bias is important for convincing judges with the assistance of social science evidence that bias exists and for satisfying legal requirements that intent be proven in some anti-discrimination cases. ${ }^{34}$ Others lament the continued focus on intent in anti-discrimination law and thus critique the growing popularity of social cognition theories. ${ }^{35}$ They maintain that rather than dispensing with intent as a dimension of anti-discrimination law and focusing instead on the impact of discriminatory conduct, implicit bias theory risks reinforcing intent requirements. They argue that it is misguided to focus on individual mental states when what is important is broader structural change. ${ }^{36}$

\section{Institutional Transformation: Breaking the Cycles of Discouragement}

Consistent with a more systemic approach to institutional inequality, Catharine Albiston emphasizes that, "inequality is the product of institutional processes, not individual animus" and "results from the structural conditions that make up major social institutions such the market, the family, and the state." 37 She focuses on how broader societal and structural forces outside of particular institutions impact upon the nature of inequality within those institutions, and asks, "How do workplace structures reinforce

32 In particular the work of Anthony Greenwald (see e.g. Anthony G Greenwald \& Linda Hamilton Krieger, "Implicit bias: Scientific foundations" (2006) 94 Cal L Rev 945).

33 See e.g. Linda Hamilton Kreiger, "The Content of Our Categories: A Cognitive Bias Approach to Discrimination and Equal Employment Opportunity” (1995) 47 Stan L Rev 1161; Charles R Lawrence III, “The Id, the Ego and Equal Protection: Reckoning with Unconscious Racism” (1987) 39 Stan L Rev 317; Samuel Bagenstos, "Implicit Bias, 'Science' and Anti-Discrimination Law" (2007) 1 Harv L Rev 477; Linda Hamilton Kreiger \& Susan Fiske, "Behavioral Realism in Employment Discrimination Law: Implicit Bias and Disparate Treatment" (2006) 94 Cal L Rev 997 ; Lee, supra note 31; Patrick Shin, "Liability for Unconscious Discrimination? A Thought Experiment in the Theory of Employment Discrimination Law" (2010) 62 Hastings LJ 67.

34 See e.g. Jerry Kang et al, "Implicit Bias in the Courtroom" (2012) 59 UCLA L Rev 1124; Eva Paterson, "Litigating Implicit Bias" in Chester Hartman, ed, America's Growing Inequality: The Impact of Poverty and Race (Lanham, MD: Lexington Books, 2014) 63; Justin D Levinson \& Robert J Smith, eds, Implicit Racial Bias Across the Law (Cambridge: Cambridge University Press, 2012).

35 See e.g. Ralph Richard Banks \& Richard Thompson Ford, "(How) Does Unconscious Bias Matter?: Law, Politics, And Racial Inequality" (2008-2009) 58:5 Emory LJ 1053. This continued focus on intent has not characterized Canadian antidiscrimination law, although some judges are moving in that direction: see Quebec (Attorney General) $v$ A, $2013 \mathrm{SCC} 5$ at para 179, [2013] 1 SCR 61, LeBel J.

36 See Banks \& Ford, ibid. They also suggest that implicit bias theory is 'political pandering' to try to make people feel better about being racist: "[ $\mathrm{t}$ ] he invocation of unconscious bias levels neither accusation nor blame, so much as it identifies a quasi-medical ailment that distorts thinking and behavior. People may be willing to acknowledge the possibility of unconscious bias within themselves, even as they would vigorously deny harboring conscious bias" at 1054.

37 Catharine Albitson, "Institutional Inequality" (2009) Wisconsin L Rev 1093 at 1094 [emphasis added] [Albitson], citing Peter L Berger \& Thomas Luckmann, The Social Construction of Reality: A Treatise on the Sociology of Knowledge (New York: DoubleDay, 1966). 
traditional, historically contingent conceptions of gender or race, regardless of individual animus?"38 Albiston critiques traditional anti-discrimination law for failing to question institutional norms and structures, and its tendency to provide special treatment and accommodation that entrenches the social meaning of group-based identities. Instead, she advocates an approach whereby institutional norms and practices are transformed:

Rather than focusing solely on prohibiting discrimination on the basis of the already socially constructed category [...] one might ask directly what work should look like, and enact specific, substantive modifications of institutionalized work practices that generate institutional inequality. ${ }^{39}$

Such an approach changes workplace norms and practices for everyone, "rather than carving out small exceptions to a largely unchanged work environment that continues to recreate relations of inequality." 40

In the Canadian context, there is a rich and extensive scholarship on transformative approaches to anti-discrimination law. Feminist scholars Gwen Brodsky and Sheila Day, for example, have emphasized the ways in which accommodation risks reinforcing rather than challenging dominant norms by allowing "those who consider themselves 'normal' to continue to construct institutions and relations in their image, as long as others, when they challenge this construction are 'accommodated:", 41

Accommodation does not go to the heart of the equality question, to the goal of transformation, to an examination of the way institutions and relations must be changed in order to make them available, accessible, meaningful and rewarding for the many diverse groups of which our society is composed. Accommodation seems to mean that we do not change procedures or services, we simply "accommodate" those who do not quite fit. We make some concessions to those who are "different", rather than abandoning the idea of "normal" and working for genuine inclusiveness. ${ }^{42}$

In an important Supreme Court of Canada decision on gender-based discrimination which endorsed an approach to anti-discrimination law sensitive to the need to re-examine workplace norms and standards, Chief Justice McLachlin critiqued the doctrinal approach in place at the time which, she maintained, left

38 Albitson, ibid at 1097. For a discussion of the broadening scope of equality rights analysis, see Colleen Sheppard, "Mapping anti-discrimination law onto inequality at work: Expanding the meaning of equality in international labour law” (2012) 151 International Labour Review 1. See also, Ian F Haney Lopez, "Institutional Racism, Judicial Conduct and a New Theory of Racial Discrimination" (2000) 109 Yale LJ 1717; Samuel Bagenstos, "The Structural Turn and the Limits of Antidiscrimination Law" (2006) 94 Cal L Rev 1; Tristan Green, "Discrimination in Workplace Dynamics: Toward a Structural Account of Disparate Treatment Theory" (2003) 38 Harv CR-CLL Rev 91; Sturm, "A Structural Approach", supra note 9.

39 Albitson, supra note 37 at 1154.

$40 \quad$ Ibid at 1165. See also, Lauren B Edelman et al "When Organizations Rule: Judicial Deference to Institutionalized Employment Structures" (2011) 117 American Journal of Sociology 888.

41 Shelagh Day \& Gwen Brodsky, "The Duty to Accommodate: Who Will Benefit?" (1996) 75 Can Bar Rev 433 at 462.

42 Ibid cited with approval by McLachlin CJ writing immediately after the quotation: "I agree with the thrust of these observations. Interpreting human rights legislation primarily in terms of formal equality undermines its promise of substantive equality and prevents consideration of the effects of systemic discrimination [...]." See Meiorin, supra note 6 at para 41 . 
"the complex web of seemingly neutral, systemic barriers to traditionally male-dominated occupations [...] beyond the direct reach of the law." "43 As a result, McLachlin C.J. noted:

The right to be free from discrimination is reduced to a question of whether the "mainstream" can afford to confer proper treatment on those adversely affected, within the confines of its existing formal standard. If it cannot, the edifice of systemic discrimination receives the law's approval. This cannot be right. ${ }^{44}$

Articulating the importance of more transformative approaches is a critical first step to building more inclusive and equitable institutions. Yet how do we go from inspirational rhetoric and individual remedies to social and institutional transformation? While legislative reform, including innovations in proactive equity regulatory initiatives, is important, it is very difficult to change institutions through legislation. Indeed, institutions and communities often resist imposed legislative change, resulting in what Linda Kreiger calls "socio-legal backlash." 45 Building institutional equality requires engagement with processes of institutional change - processes that break cycles of discouragement, transform institutional cultures, contest institutionalized vulnerability, reinforce individual and group agency, and reverse the dynamics of courage away from discouragement. Legal norms securing protection for equality and non-discrimination are vital normative guideposts, but they provide a starting point rather than an endpoint for social and institutional transformation.

\section{SECOND DYNAMIC OF COURAGE: ENCOURAGEMENT AND INSTITUTIONAL CHANGE-MAKERS}

Turning to the second, much more positive dynamic of courage, there is a significant body of scholarship theorizing and documenting the critical role of individuals as agents of institutional change and transformation. ${ }^{46}$

\section{A. Organizational Catalysts/Institutional Mediators}

According to Sturm, "second generation manifestations of workplace bias are structural, relational and situational [...]." As such, she argues that they cannot be regulated pursuant to "a fixed code of specific rules or commands that establish clear boundaries governing conduct. Instead, their resolution requires a different process, namely problem solving." 48 Her work, therefore, "explores the potential for

43 Meiorin, ibid at para 42.

44 Ibid.

45 Supra note 2. For a discussion of this phenomenon in the Canadian context, see Colleen Sheppard, "Constitutional Equality and Shifting Conceptions of the Role of the State: Obstacles and Possibilities" in Sanda Rodgers, Sheila McIntyre \& Mary Eberts, eds, Strategizing Systemic Inequality Claims: Equality Rights and the Charter (Toronto: LexisNexis, 2006) 251-268.

46 Highlighting the role of individual as agents of change, of course is just one small lens through which to examine the complex and extensive debates around institutional change. For insights into these larger debates, see e.g. Jame Mahoney \& Kathleen Thelen, Explaining Institutional Change: Ambiguity, Power and Agency (Cambridge: Cambridge University Press, 2010) (discussing both endogenous and exogenous factors in institutional change.)

47 Sturm, "A Structural Approach", supra note 9 at 473.

48 Ibid at 475 [references omitted]. 
a de-centred, holistic, and dynamic approach to these more structural forms of bias." ${ }^{\text {"49 }}$ Such a regulatory approach rejects an exclusive reliance on a retroactive individual complaints model of compliance with anti-discrimination laws and workplace rules. Instead, equality is built at the interstices of numerous, everyday institutional decisions.

To ensure a proactive and effective structural approach to persistent institutional inequalities, Sturm emphasizes the importance of informed and empowered organizational catalysts or institutional intermediaries. ${ }^{50}$ These individuals play a critical role in "translating and mediating between formal law and workplace practice." 51 Focusing on the university context, Sturm reminds us that, "women and people of color face cognitive biases in evaluation, exclusion from informal networks, and underinclusive definitions of success." ${ }^{52}$ In addition, there continues to be a lack of understanding and awareness of the inequalities that "outsider" scholars continue to face. ${ }^{53}$ In seeking to enhance equitable institutional decision-making, Sturm maintains that there must be greater "institutional attentiveness across the spectrum of decisions that ultimately determine whether women and men of all races will have the opportunity to thrive, succeed, and advance." ${ }^{, 54}$ Sturm writes:

This institutional attentiveness can be developed by building the organizational catalyst role into the architecture of a change initiative. This is achieved by creating institutional roles that place people with knowledge, influence, and credibility in positions to influence practice at pivotal locations where gender and racial biases operate. ${ }^{55}$

According to Sturm, organizational catalysts are people who have the following characteristics. First, they occupy "boundary-spanning institutional" positions, which allows them to "operate at the convergence of different domains and levels of activity" ${ }^{56}$ Second, they "have the capacity to leverage legitimacy and have links to traditional power and constituencies for gender and racial justice", playing what Sturm calls a "hybrid role" mediated by "knowledge, legitimacy and social capital."57 Thirdly, they organize their workplace engagements around "institutional projects and problems" providing an "overarching conceptual framework for pursuing inclusiveness, one that connects an understanding of the culturally and institutionally rooted dimensions of the problem to programmatic intervention, system design, and institutional change. ${ }^{, 58}$ And lastly, they "sustain networks by distributing leadership." 59

$49 \quad$ Ibid at 462 .

50 See Susan Sturm, "The Architecture of Inclusion: Advancing Workplace Equity in Higher Education” (2006), 29

Harvard JL \& Gender 247 [Sturm, "Architecture of Inclusion"], where she explains at 250: "Organizational catalysts act as information entrepreneurs and bridge builders at pivot points that can leverage change. The need for their role stems from the institutional underpinnings of persistent bias."

Ibid at 251

53 See Richard Delgado, “The Imperial Scholar Revisited: How to Marginalize Outsider Writing, Ten Years Later” (1992) U Pa L Rev 1349.

54 Sturm, “Architecture of Inclusion”, supra note 50 at 251.

55 Ibid.

56 Susan Sturm, "The Architecture of Inclusion: Interdisciplinary Insights on Pursuing Institutional Citizenship, Conclusion" (2007) 30 Harvard JL \& Gender 409 at 418.

57 Ibid.

58 Ibid at 419. 
Thus, organizational catalysts operate effectively across divides of privilege and difference. Sensitive to the realities of exclusion, they are situated to promote inclusion and institutional change.

It is interesting to speculate as to what prompts some individuals to play the role of institutional change agent while others choose much more conformist roles, accepting more readily dominant institutional visions and norms. Sturm's vision is premised on the active and engaged commitments of institutional mediators - individuals whose lives bridge multiple communities and worlds - who are partly inside and yet partly outside the halls of power and privilege. While there are no doubt pressures to assimilate and conform, many individuals resist such pressures and continue to advocate on behalf of underrepresented and socially disadvantaged communities and groups.

What is the role of law in reinforcing the potential for individuals to act as institutional changemakers? In some instances, legislative and policy initiatives and/or judicial decisions can identify a role for organizational agents of change. ${ }^{60}$ In addition, regulatory frameworks can ensure the institutional infrastructures, policies and legal protections that reinforce the agency of organizational catalysts by according them the resources, support and security they need to act as catalysts for organizational change (i.e. job security and tenure). Kathyrn Abrams' work on "partial agency" is also relevant here, as it resonates with the idea of experiencing power and disempowerment simultaneously. ${ }^{61}$ Abrams emphasizes the potential role of law and legal remedies in reinforcing partial agency, a strategy that could also be usefully applied to institutional change agents.

\section{B. Mentoring}

Another lens through which to examine the critical role of individuals in promoting inclusion and equality is that of mentoring. The mentor (who may well be an institutional mediator or organizational catalyst) nurtures a relationship with another individual, usually across an institutional power, knowledge and experiential divide. As Sarah Hawkes notes, "In Homer's The Odyssey, Ulysses entrusted his son, Telemachus, into the care of Mentor, who was old and wise and took charge of Telemachus' education, helping him to mature, learn courage, honesty and a commitment to serving others." $" 62$ In her literature review of mentoring, however, Hawkes also identifies the risks of inequality in access to mentoring relationships, particularly in relation to informal mentoring. She cites research that documents the difficulty women and racialized groups have in finding mentors. ${ }^{63}$ Despite the problem of inequitable access to mentors, when it has been available, mentoring has been shown to be an effective means for addressing the underrepresentation of women and other historically excluded

59 Ibid. I believe that Judge Juanita Westmoreland-Traoré has been an organizational catalyst in multiple institutional contexts.

60 For example, independent ombudspersons may be formally-recognized agents for change and play a role in conflict resolution: see online: International Ombudsman Association $<$ http://www.ombudsassociation.org/>.

61 Kathryn Abrams, "Sex Wars Redux: Agency and Coercion in Feminist Legal Theory” (1995) 95 Colum L Rev 304.

62 Sarah Hawkes, "Supporting women's mentoring in Higher Education: a literature review" (2010) online: Equality Challenge Unit $<$ http:/www.ecu.ac.uk/publications/files/supporting-womens-mentoring-in-higher-education-literaturereview.doc/view $>$.

63 Ibid at 6, citing RM Kanter, Men and women of the corporation (New York: Basic Books, 1977); C Lewellen-Williams et al, "The POD [Peer-Onsite-Distance]: a new model for mentoring underrepresented minority faculty" (2006) 81:3 Academic Medicine 275-279. Hawkes delineates three forms of mentoring: peer mentoring, informal and formal mentoring. 
groups in senior positions. Of significance is the shift towards institutionalizing alternatives to the traditional informal mentoring in the form of more formal institutional mentoring initiatives and peer mentoring. ${ }^{64}$

In her article on "Mentoring the other: cultural pluralist approaches to access to justice," Adelle Blackett describes mentoring as a process that "is very much about building relationships across differentials in age, experience, power, with the explicit purpose of expanding the life options or advancing the career of the mentee." ${ }^{65}$ Yet, she cautions that as an informal mechanism for the sharing and transmission of institutional and professional knowledge and social capital, mentoring processes "may simultaneously be sites that reproduce exclusionary practices and affirming spaces to promote inclusion." In Indeed, historically, mentoring has operated both to reinforce the reproduction of institutional inequality and to assist individuals in securing equitable inclusion within social institutions and professions. The risks include the tendency for those whose lives mirror those of the dominant group within an institution to benefit disproportionately from informal mentoring relationships, while outsider groups are left without effective mentoring relationships. There is also a risk that "mentoring the other" will secure advancement and inclusion by promoting the assimilation and conformity to dominant norms and practices. Though Blackett critically explores these risks, she acknowledges the positive potential of mentoring, even across a divide of difference, to provide access to equitable inclusion to individuals who have been historically excluded from certain institutions and professions. As Blackett writes: "Mentoring the other, subject to important correctives, may provide a valuable complement to formal access channels, to the extent that it promotes deeper educational, and crosscultural engagements." ${ }^{, 67}$

Mohawk legal scholar Patricia Monture's insights regarding the integral connection between equality and caring also resonate with the practice of mentoring. As Monture explains, "In order to understand equality, people must understand caring. [...] Each person must be respected for whom and what they are. Only when we all understand caring will we have reached equality." 68 This idea underscores the ways in which equality is forged in relationship with others, and that human flourishing towards equality requires a community context of care and support. ${ }^{69}$ It contemplates taking responsibility for helping and encouraging others to fulfil their potential.

\section{THIRD DYNAMIC OF COURAGE: ENCOURAGEMENT AND SOLIDARITY}

The Cowardly Lion [in the iconic Wizard of Oz film] ultimately discovers the essence of courage not in himself, not by meeting the wizard, and not even by acting with particular bravery; courage comes to the

64 See also, Colleen Sheppard \& Sarah Westphal, "Equity and the University: Learning from Women's Experience" (1992) 5 CJWL 5.

65 Adelle Blackett, "Mentoring the other: cultural pluralist approaches to access to justice" (2001) International Journal of the Legal Profession 275 at 277.

${ }_{66}^{6}$ Ibid at 276.

67 Ibid at 282.

68 Patricia Monture, "Ka-Nin-Geh-Heh- Gah-E-Sa-Nonh-Yah-Gah” (1986) 2 CJWL 159 at 159.

69 Monture's ideas have deeply influenced my own work on the importance of a relational conception of equality, nurtured by relations of care and democracy: See Sheppard, Inclusive Equality, supra note 1 at 103-118. 
cowardly lion when he perseveres in the midst of hardship and does not give up on his friends when they need him. ${ }^{70}$

A third dynamic of courage is encouragement through solidarity and collective engagement. Individuals at the bottom of institutional hierarchies may not have the power or ability to instigate change on their own; yet, by working together with others, they are empowered and may become a significant force for institutional transformation. Similarly, having a supportive peer, community and family context is critical to creating the conditions where individuals can participate in initiatives for institutional change and/or voice their concerns about inequalities in their lives and communities. Indeed, scholarship on narratives and experiential outsider knowledge emphasizes the importance of a supportive and capable audience for storytellers. ${ }^{71}$ Individuals will not share concerns and insights about their lives if they are in an environment of disbelief, disempowerment or disdain. ${ }^{72}$ As Lynda Alcoff posits, "Our power relationships to those with whom we are speaking and our sense and knowledge of ourselves as well as our experiences will be changed by the structural arrangements of the discursive event." ${ }^{.73}$ In advocating for the importance of voice, it is critical to be attentive to the conditions under which speech takes place so as not to re-inscribe inequalities through the ways in which outsider narratives are told or received.

In her work on courage and organizational change, Monica Worline defines courage as "a pattern of constructive opposition, where an individual stands against social forces in order to remedy duress in the organization." "74 She describes the "dynamic of constructive opposition" as "a particular moment in social life when an individual expresses the capacity to act separately from the social forces in which he [or she] is immersed in order to protect or advance the collective good in some way." "75 Beyond explaining individual acts of courage in opposition to the institutional status quo (an idea that resonates with organizational catalysts), "the notion of courage may be important to forming collective identity and coordinating collective action." ${ }^{, 76}$ With respect to both individual and collective acts of courage, scholars maintain that "courageous action is constructive, because a person or collective engages in actions of moral or social worth, but also confrontational, because the actor is moving in ways that are opposed to the ongoing norms, social pressures, expectations, and flow of events., ${ }^{, 7}$

In a poignant article on courage and collective action, "Enabling Courageous Collective Action: Conversations from United Airlines Flight 93," Monica Worline and Ryan Quinn examine how the

70 Monica C Worline, "Courage in Organizations: An Integrative Review of the "Difficult Virtue"' in Gretchen M Spreitzer \& Kim S Cameron, eds, The Oxford Handbook of Positive Organizational Scholarship (New York: Oxford University Press, 2011) at 23 [Worline].

71 Colleen Sheppard \& Sarah Westphal, "Narratives, Law and the Relational Context: Exploring Stories of Violence in Young Women's Lives" (2000) 15 Wis Women's LJ 335.

72 Ibid at 347-8.

73 Lynda Alcoff Martin \& Laura Gray, "Survivor Discourse: Transgression or Recuperation?” (Winter 1993) 18 SIGNS 260.

74 Worline, supra note 70 at 6 . As she notes at 13: "When and how people choose to speak up in organizations is a prime area for future research that links courage to broader issues in organizational studies."

75 Ibid at 8. See also Monica Worline, Dancing the cliff edge: the place of courage in social life (PhD Thesis, University of Michigan, 2004) [unpublished].

76 Ibid at 16, citing Ryan W Quinn \& Monica C Worline, "Enabling Courageous Collective Action: Conversations from United Airlines Flight" (July/August 2008) 93 Organization Science 497 [Quinn \& Worline].

77 Ibid at 498 . 
passengers on the fated flight 93 on September $11^{\text {th }}$ were prompted to take courageous collective action, in their efforts to retake control of their aircraft in the face of its hijacking by terrorists:

\begin{abstract}
We propose that to take courageous collective action, people need three narratives - a personal narrative that helps them understand who they are beyond the immediate situation and manage the intense emotions that accompany duress, a narrative that explains the duress that has been imposed upon them sufficiently to make moral and practical judgments about how to act, and a narrative of collective action - and the resources that make the creation of these narratives feasible. ${ }^{78}$
\end{abstract}

Significantly, Worline and Quinn emphasize the importance of strong external, familial and social sources of support, an analytical framework for understanding problems, and the importance of forging a collective identity to sustain courageous action. Although they develop their analysis in the context of a terrorist incident, they gesture towards its applicability to organizational change and collective action more broadly. Indeed, if organizations are to remain dynamic, acts of individual and collective courage should be celebrated and resourced.

How do these insights from organizational studies impact upon law and institutional inequality? One of the legal and organizational mechanisms for securing autonomous workplace spaces in which to hear the voices of those with less power is trade unionism. In its jurisprudence on freedom of association and unionization, the Supreme Court of Canada has recognized solidarity amongst workers as a critical means for securing basic fairness in conditions of work. As noted by Chief Justice Dickson, "Historically, workers have combined to overcome the inherent inequalities of bargaining power in the employment relationship and to protect themselves from unfair, unsafe, or exploitative working conditions." $" 79$ Significantly, the Court has also emphasized that labour unions, through collective bargaining, contribute to the democratization of the workplace:

[A] constitutional right to collective bargaining is supported by the Charter value of enhancing democracy. Collective bargaining permits workers to achieve a form of workplace democracy and to ensure the rule of law in the workplace. Workers gain a voice to influence the establishment of rules that control a major aspect of their lives. ${ }^{80}$

Thus, in the context of the modern workplace, democratic engagement and the endorsement of mechanisms for hearing the voices of those at the bottom of institutional hierarchies have been affirmed in our constitutional jurisprudence. ${ }^{81}$ Yet there remain significant challenges to forging a robust conception of citizenship at work. ${ }^{82}$

$78 \quad$ Ibid at 497.

79 Reference Re Public Service Employee Relations Act (Alta.), [1987] 1 SCR 313 at para 23 [Alberta Reference], cited with approval in majority decision in Health Services and Support-Facilities Subsector Bargaining Assn. v British Columbia, [2007] 2 SCR 391 at para 84 per McLachlin CJ [Health Services].

80 Health Services, ibid at para 85, citing Lavigne v Ontario Public Service Employees Union, [1991] 2 SCR 211 at 260-61, per Wilson J. See also Alberta Reference, ibid at 369; Dunmore v Ontario (Attorney General), [2001] 3 SCR 1016 at paras 12 and 46.

81 On the intersection of collective bargaining and equality, see Adelle Blackett \& Colleen Sheppard, "Collective Bargaining and Equality: Making Connections" (2003) 142 International Labour Review 419. For a discussion of the potential of labour law to address both redistribution and representation, see Adelle Blackett, "Emancipation in the Idea of Labour Law," in Guy Davidov \& Brian Langille, eds, The Idea of Labour Law (Oxford, UK: Oxford University Press, 
Another area of legal regulation pertinent to enhancing courageous actions within organizations is work-life balance. ${ }^{83}$ Studies on organizational change and individual and collective courage underscore the importance of ensuring that individuals have strong social and family support networks outside of the organization. As Worline and Quinn suggest, "when people receive sanction from others who play relevant and important roles in their life narratives, it helps them manage the emotions of extreme duress through mutual connection with another [...] and through validation of one's identity." 84 Thus, workplace policies and laws that value family and personal relationships outside of the workplace sustain individuals as institutional citizens, who then are empowered to act courageously.

Finally, enhancing legal protections for collective action outside of the work context is also critical to facilitating solidarity and collective initiatives for equality and inclusion. Student governance organizations and associations, consumer protection and community-based organizations deserve to be supported and encouraged as structural mechanisms for enhancing solidarity and bottom up social change. ${ }^{85}$

\section{V.CONCLUSION}

One of the recurrent insights of organizational studies research is that "courage inheres in action rather than individuals." 86 We are all both courageous and non-courageous at different moments in our lives. It is suggested, therefore, that "the question that we need to ask is not, "How do we hire courageous people?' but 'How do we engender more courageous action?", 87 This article has suggested three strategies for enhancing courage in contexts of institutional inequality. The first is to recognize the ways in which discrimination (including direct and adverse effects discrimination, implicit bias, and structural inequalities) discourages individuals and communities in tangible and intangible ways. Discouragement contributes to the entrenchment of inequality as individuals become discouraged from seeking access to inequitable institutions, experience a gradual erosion of self-esteem and confidence, and continue to be denied equitable inclusion or evaluation.

A second strategy explored in this article is that of affirming and reinforcing the role of institutional change agents or organizational catalysts. The leadership of individuals who bridge communities of privilege and social disadvantage has had a critical impact in prompting institutional change and

2011), online: Oxford Scholarship Online $<\mathrm{http}: / /$ www.oxford-

scholarship.com/view/10.1093/acprof:oso/9780199693610.001.0001/acprof-9780199693610-chapter-26>.

82 See Judy Fudge, “After Industrial Citizenship: Market Citizenship or Citizenship at Work?” (2005) 60:4 Relations industrielles / Industrial Relations 631, online: Eridit <http://www.erudit.org/revue/ri/2005/v60/n4/012-338ar.pdf>

83 For an extended discussion, see Colleen Sheppard, "Individual accommodation versus institutional transformation: two paradigms for Reconciling paid work and family responsibilities", in Barreau du Québec \& Tribunal des droits de la personne, Les 15 ans du tribunal des droits de la personne et les 30 ans de la charte des droits et libertés de la personne (Cowansville: Yvon Blais, 2005), 379.

84 Quinn \& Worline, supra note 76 at 505 [references omitted].

85 See Christian Brunelle, Louis-Philippe Lampron \& Myriam Roussel, "La liberté d'expression en contexte de crise: Le cas de la grève étudiante" (2012) 53:4 Cahiers de droit 831.

86 Ryan Quinn, "Where is the Courage in Organizations?" (13 April 2009), Lift Consulting (blog), online: $<$ http://www.leadingwithlift.com/blog/2009/04/13/where-is-the-courage-in- organizations/\# sthash .yKd8sCXv.dpuf $>$.

87 Ibid. 
securing the inclusion of individuals who would otherwise be overlooked and/or undervalued. Whether as institutional mediators or mentors, engaged and committed individuals play critical roles in creating the conditions and practices of equality in the everyday moments of institutional life. It is important, therefore, to recognize the role of organizational catalysts in enhancing institutional attentiveness to inequality and the importance of equitable mentoring for individuals from communities traditionally underrepresented within an institution. Ensuring institutional safeguards to allow individuals to flourish as organizational catalysts means creating legal and regulatory frameworks that protect individuals from negative consequences if their views or actions challenge the institutional status quo. It also means that individuals will be accorded adequate time and resources to allow them to participate in meaningful engagement in organizational change and mentoring.

The third strategy for enhancing institutional equality focuses on the ways in which individuals are encouraged to seek their rightful place in organizations, and to participate in institutional change in environments where peer support and collective action by those at the bottom of institutional hierarchies are valued and supported. Individuals rarely transform longstanding exclusionary practices and policies on their own; rather, collective action and engagement prompt bottom-up initiatives for organizational change. Thus, in thinking about how best to advance equality in institutions, it is important to be attentive to legal and regulatory mechanisms for strengthening the voices of those who have been historically underrepresented in positions of power and privilege.

These strategies suggest some pathways forward in transforming dynamics of courage away from discouragement towards encouragement. In her life's work contributing to social justice and the communities around her, the Honourable Judge Westmoreland-Traore has affirmed the power of encouragement. Both her courage and encouragement have been vital to so many of us in making us stronger, braver and more intelligent than we ever imagined we could be, and in teaching us about how we can and must encourage those around us. ${ }^{88}$

${ }^{88}$ See supra note 3, and accompanying text. 